\title{
Short Analysis Review of Developing Method Study in Integrating Science, Technology, Engineering, and Mathematics (STEM) Approach in Problem Based Learning Model towards Students' Problem Solving Ability
}

\author{
Dewi Rahmadani \\ Department of Physics Education \\ Postgraduate School of Indonesia University of Education Bandung, Indonesia \\ dewirahmadani_physics@yahoo.com
}

\begin{abstract}
The present study aims analyze the theory at developing method study of integrating STEM approach to Problem Based Learning model and its correlation with students' problem solving ability. Problem solving is students' ability to use knowledge and concepts learnt in solving some problems in daily life. Problem solving ability is one of abilities that should be obtained by students. Thus, its learning process also should be adapted. Problem based learning model is one of learning models, which presents real problems as the basic foundation in the learning process. However, daily life problems are much more complex over technology development, so that a learning process, which focuses on science and technology development is needed. At the present time, there is a development of Science, Technology, Engineering, and Mathematics (STEM) model in education. This model will be developed with environment, so that a learning process, which presents students' real life is created. This is suitable with the essence of Problem Based Learning model, so learning process is believed to be able to drill students' problem solving ability. In fact, it is not only regarding the process of solving some problems mathematically, but it is also regarding the process of solving concrete problems since in learning activities, students do not only learn theoretically, but they are also demanded to apply the theories obtained during the learning process.
\end{abstract}

Keywords- STEM Approach; Problem Based Learning; Problem Solving Ability

\section{INTRODUCTION}

Technology development could not be got rid of from our life. Even, at the present time, we are much depended on technology. Sudents should be closed with the technologies, not only to use it but also how they are designed to facilitate human life. Thus, with their understanding towards technology, they will be interested to create a lot of technology.

Education is one of important factors which underlies technology development. The quality education will produce intellectual future generation so that they are able to create superior technology products. This could be constructed in students self at very first, but the present learning process commonly tends to have lack of technology literacy. Apriyanto states that in order to enable students to produce an innovative product, the learning process should not be monolitic. The learning process should be integrative. The learning process should emphasize on multidiscipliner, interdiscipliner, and transdiscipliner investigation. One of ways to do this is by applying Science, Technology, Engineering, and Mathematics (STEM) approach [1] (cited in Mayasari, 2014).

In the present time, we know the term 21st Century Skills which is a skill needed in 21 st century. It is also the demand in current education. So the learning process should also be adapted with learning objective. National Research Council states that science learning should be emphasized on fundamental comprehension since from the comprehension, the other cognitive competences will also be developed well [2]. Good comperehension aims at enabling students to solve complex problems so that students are able to solve daily life problems easily. Thus, problem based learning is needed.

\section{RESEARCH METHOD}

The present study uses a quantitative. The research method is quasi experiment with the matching pretest-posttest control group design.

\section{RESULTS AND DISCUSSION}

Gallant states that STEM approach is very effective to bridge students' conceptual comprehension among science disciplines or the other lessons and to increase students' interest to STEM approch itself [3]. Bybee argues that learning through STEM aims at enabling students to obtain science literacy and technology if they involve in society later on as well as they are able to develop their competence to be applied when they solve societial problems regarding STEM field [1]. Additionally, Marison describes some characteristics of STEM education for students, schools, and classes. STEM educates students to be problem solver, logical thinker, 
technology literate, and enables students to connect their cultures with their learning [3].

There is a suitability between skills in 21 st century and STEM basic principles. Learning design in 21 st century started from identifying themes and concepts which involves some lesson contents. Through the integration among science, technology, engineering, and mathematics, STEM curriculum has been an example of cross-curricular learning which is as the foundation learning curriculum in 21 st century.

To prepare students' career in the future, they should be involved in daily life problems which is in line with STEM principles. Students work together to create innovative solution towards daily life problems and communicate their solution to the others. Instead of working to fulfil their responsibility, students also build their life skills and career by learning to budget their time, being independent and working in groups. STEM education could be developed if it is integrated with environment, so that a learning which presents real life is created [1].

TABLE I. CORRELATION PROBLEM BASED LEARNING SyNTAX INTEGRATIVE STEM APPROACH AND SOLVING PROBLEM ABILITY WHICH IS DRILLED

\begin{tabular}{|c|c|}
\hline $\begin{array}{l}\text { Problem Based Learning Syntax } \\
\text { Integrative STEM Approach }^{\mathrm{a}}\end{array}$ & $\begin{array}{c}\text { Solving Problem Ability which } \\
\text { is Drilled }\end{array}$ \\
\hline $\begin{array}{l}\text { Phase } 1 . \\
\text { Introduction }\end{array}$ & $\begin{array}{l}\text { - Understanding words and } \\
\text { contexts }\end{array}$ \\
\hline Phase 2. Organization overview & - Using analogy \\
\hline $\begin{array}{l}\text { Phase } 3 . \\
\text { Problem statement }\end{array}$ & $\begin{array}{l}\text { - Identifying mismatched problems } \\
\text { - Giving reasons for complex } \\
\text { problems } \\
\text { - Formulating problems in the } \\
\text { form of question }\end{array}$ \\
\hline $\begin{array}{l}\text { Phase } 4 . \\
\text { Problem discussion } \\
\text { There are four steps in this process: } \\
\text { 1. Problem Analysis } \\
\text { 2. Independent Research } \\
\text { 3. Brainstorming } \\
\text { 4. Solution Testing }\end{array}$ & $\begin{array}{l}\text { - Identifying problems } \\
\text { - Finishing coincidentally } \\
\text { - Selecting own problem } \\
\text { - Describing problems } \\
\text { - Identifying assumption } \\
\text { - Solving problems based on data } \\
\text { and problems } \\
\text { - Giving reasons for solution } \\
\text { - Evaluating the quality of solution }\end{array}$ \\
\hline $\begin{array}{l}\text { Phase } 5 . \\
\text { Problem solution }\end{array}$ & $\begin{array}{l}\text { - Evaluating systematic strategy } \\
\text { - Describing various kinds of } \\
\text { strategy } \\
\text { - Giving the other strategies } \\
\text { - Giving reasons for strategy used }\end{array}$ \\
\hline
\end{tabular}

${ }^{\mathrm{a}}$ Dischino, 2011[6]

Problem based learning model is one of learning models which presents real facts to be the basic foundation in the learning process. This is in line with the essence of STEM learning. Problem based learning model is a set of teaching model which uses problems as the focus in developing students' ability in solving the problems, subjet matters, and self-management [4]. Problem based learning is used widely such as in medical schools in 1970s. Problem based learning is an interesting alternative for traditional based method in the fields of technical and technology [5]. STEM is an interdiscipliner approach and applied to teach science, technology, fiction, and mathematics integratively. STEM instruction fouses on hands-on, problem based learning and real life application. STEM aims at preparing students to enable them to master skills in 21 st century and is ready to learn and take career in STEM field.

The steps in Problem based learning integrated with STEM approach have been modified by inserting STEM context in its cycles. Problem based learning with integrative STEM contains five adding information as the learning source (script, website, work sheet, etc) in attempt to guide students through problem solving process.

This learning process started from aspect $\mathrm{T}$ (techology), since technology could be desribed easily and connected with real life, where technology is a modification of natural world to get the need of human beings as the solution to some problems existed. In the next steps, to build technology, students need to understand science and mathematics that support that design. Thus, SM (science and mathematics) takes an important role. To plan and solve the problems technically fiction aspect or E (engineering) is really needed. The application of this method is used to facilitate students in comprehending learning process wholly [7].

In this theory analyses, problems solved are not the problems, which have been drilled to solve. Problems in this context defined as a situation where the objective could not be achieved if teachers just apply traditional procedures or have been drilled formerly [8]. So that students are able to solve the new problems in their surrounding.

\section{CONCLUSION}

Based on the results of study, it is concluded that integrative STEM approach in problem based learning helps students conduct useful learning since integrative STEM integrate concepts and concrete problems in students' daily life. In addition, problem based learning presents problems which happen in daily life, encourages students to solve the problems through conceptual comprehension during the learning process.

\section{Acknowledgment}

The author would like to thank to Bu Selly Feranie and $\mathrm{Bu}$ Irma Rahma Suwarma whose generous advices guided the research.

\section{References}

[1] Mayasari Tantri, (2014). Learning Effect of Integrated Science, Technology, Engineering, and Mathematics (STEM) On Learning Outcomes. Proceedings Semnas Pensa VI "The Role of Science Literacy".

[2] National Research Council (2011). A Framework for K-12 Science Education: Practices, Crosscutting Concepts, and Core Ideas. Published by The National Academic Press at http://www.nap.edu/catalog.php?record id=13165

[3] Gallant, D.J. (2011) Science, Technology, Engineering, and Mathematics (STEM) Education. School of Education Policy and Leadership The Ohio State University

[4] Edgen, P \& Kauchak, D. (2012). Strategy of Teaching Model. Jakarta: PT. Indeks. 
[5] Massa, N. et all. (2012). Problem Based Learning in a Pre-service Technology and Engineering Education Course. America: American Society for Engineering Education.

[6] Dischino, M. (2011). Increasing the STEM Pipeline through ProblemBased Learning. Proceedings of the 2011 IAJC-ASEE International Conference. ISBN 978-1-60643-379-9

[7] Saito, T., Okumura, J. \& Kumano, Y. (2013). The STEM Education Research in Japan and Its Prospective. Disajikan pada Kuliah Umum tentang Science Technology Engineering and Mathematics (STEM), 27 Desember 2013, UPI, Bandung

[8] OECD (2014). PISA 2012 Results: Creative Problem Solving: Students' Skills in Tackling Real Life Problems (Volume V). PISA: OECD Publishing. 